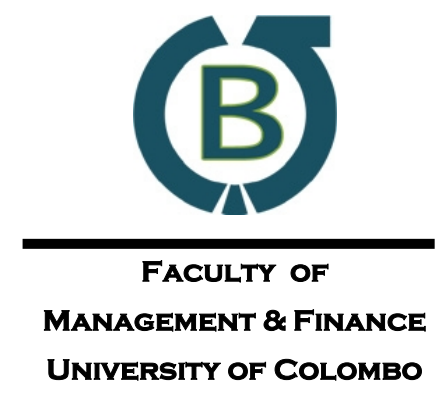

UNIVERSITY OF COLOMBO
Colombo

Business

Journal

Vol. 07, No. 01, June, 2016
International Journal

of Theory \& Practice

\title{
Multi-Level Mediation in Strategic Human Resource Management: A Conceptual Framework
}

\author{
Nisha Palagolla ${ }^{\text {a1 }}$, Vathsala Wickramasinghe ${ }^{\mathrm{b}}$ \\ ${ }^{a}$ Department of Business Management, Sri Lanka Institute of Information Technology, Sri Lanka \\ ${ }^{b}$ Department of Management of Technology, University of Moratuwa, Sri Lanka
}

\begin{abstract}
This paper aims to contribute to the understanding of Human Resource Management (HRM) practices and firm performance relationship, by conceptualizing an integrated framework to explain the mediating linkage through sequential analysis of individual, job, and unit level outcomes whilst exploring contextual factors influencing this relationship. This aim is achieved by critically reviewing different strands of literature. There is an on-going debate that empirical explanations of how HRM practices influence firm performance are inconclusive, abstract, and lacking theoretical justification. In response, literature highlights a dire need of developing comprehensive integrated frameworks to explain this relationship. Thus, a theoretically and empirically driven framework is proposed by employing employee work effort, job performance, and unit performance in sequence as the intervening/mediating linkage of the proposed HRM-firm performance relationship. Future researchers may find the proposed integrated framework as a template to articulate a holistic view of this relationship.
\end{abstract}

Keywords: Contextual Factors, Strategic HRM, HRM Practices-Firm Performance Relationship, Integrated Framework

\section{Introduction}

The strategic perspective of human resource management is labelled as SHRM and it describes the effective deployment of human resource for an organization to achieve its goals (Delery \& Doty, 1996). Wright and McMahan (1992, p. 298) have defined SHRM as "the pattern of planned human resource deployments and activities intended to enable an organization to achieve its goals". Along with these notions, it denotes a macro-oriented, proactive, and long-term perspective (Malik \& Aminu, 2011) aimed at achieving strategic needs of organizations through effective management of human behaviour. Research in SHRM during the last two decades has therefore shown a dramatic interest to demonstrate the importance of HRM practices for organizational performance (Guest, 2011; Katou \& Budhwar, 2007). As a result, positive relationships between SHRM practices and firm 
performance are drawn by a substantial volume of research across the world (Arthur, 1994; Bae \& Lawler, 2000; Becker \& Huselid, 1998; Delaney \& Huselid, 1996; Huselid, 1995; Jiang, Lepak, Hu, \& Baer, 2012; Katou \& Budhwar, 2007; Paul \& Anantharaman, 2003). However, the reasoning behind these relationships is firm's human capital: the "productive capabilities of people" (Jackson \& Schuler, 1995, p. 241) which is the most influential resource in achieving a firm's objectives (Barney \& Wright, 1998; Youndt, Snell, Dean, \& Lepak, 1996). Further, the way in which a firm manages its human capital pool (HRM Practices) play a major role in firm performance (Delaney \& Huselid, 1996). Therefore, drawing from resource-based view (RBV) of the firm (Barney, 1991, 2001; Shaw, Park, \& Kim, 2013; Wright, Coff, \& Moliterno, 2013), the HRM practices have been recognized as a strategic asset/resource (Amit \& Shoemaker, 1993; Becker \& Gerhart, 1996) since they contribute to achieve competitive advantage by enhancing employees' productive capabilities towards performance requirements of a firm (Youndt et al., 1996). Further, the recent literature identifies HRM as a strategic capability since it involves complex patterns of coordination between people and other resources of a firm (Grant, 2001). However, having considered organizational dependency on its human capital pool as the key element of value creation, the importance of effective HRM is apparent and could not be undermined (Becker \& Gerhart, 1996; Snell \& Dean, 1992).

Despite the impressive research support for the positive HRM-firm performance relationship, scholars have pointed out diverse gaps in the literature where unclear process of value creation between HRM practices and firm performance is the most highlighted (Priem \& Butler, 2001). This is referred to as the 'black-box' issue in SHRM (Becker \& Huselid, 2006; Boselie, Dietz, \& Boon, 2005; Guest, 1997, 2011; Paul \& Anantharaman, 2003; Priem \& Butler, 2001; Sheehan \& Foss, 2007). For instance, Gerhart (2005) stated that this link is ambiguous without clear evidence on intervening/mediating variables. Boselie et al. (2005) analysing 104 refereed journal articles published between 1994 and 2003 confirmed that the linking mechanisms between HRM practices and firm performance are largely disregarded making it dubious of what happens at this stage. Guest (2011), based on the review of past literature argues that there is insufficient empirical evidence to explain why there is an association between HRM practices and firm performance. Thus, there is still an ongoing debate as to whether HRM-performance link exists in reality or is merely rhetoric (Oladipo \& Abdulkadir, 2011). In response, Becker and Huselid (2006, p. 915) stated that the most pressing theoretical and empirical challenge in the SHRM research is the requirement for a "clearer articulation of the 'black-box' between HRM practices and firm performance". In that sense, the integration of distinctive and sequential stages of value addition referred to as the multi-level mediation has been proposed to provide a convincing explanation for this relationship (Guest, 1997).

Moreover, the exact nature of this relationship is ambiguous than proposed in most of the previous research (Colbert, 2004; Guest, 2011; Janssens \& Steyaert, 2009; Sheehan \& Foss, 2007) since HRM-firm performance relationship is not an isolated phenomenon. Instead, it is a one which is influenced by diverse factors of the internal and external contexts of organizations (contextual factors) (Johns, 2006). There is a vast array of such contextual factors rooted from human, physical, financial, social, institutional conditions which can either be opportunities or constraints. Thus, context plays a central role in the HRM practices-firm performance relationship since the effectiveness of a firm's operations depends on its suitable match with its internal and external environments (Schuler \& Jackson, 2005). However, these factors are completely overlooked or have been paid a narrow focus in past empirical models (Singh, Darwish, Costa, \& Anderson, 2012). Therefore, extant HRM practices-firm performance frameworks without sufficient attention to the influence of these factors 
are less practical as HRM is not static across different organizational contexts and not the only determinant of firm performance. Also, HRM constitutes a vast array of different practices such as selection, training, performance appraisal, grievance handling, communication etc., yet most of prior studies are limited to certain practices that limit their contribution to theory and practice (Opatha, 2008). Further, most of prior frameworks solely depend on financial dimensions to measure firm performance although it has been a multi-dimensional variable of both financial and non-financial aspects (Gomes, Yasin, \& Lisboa, 2011; Kaplan \& Norton, 2005). On these bases, scholars emphasized the dire need of improving existing theoretical and analytical frameworks for providing a clear and coherent understanding of the HRM-firm performance relationship (Colbert, 2004; Guest, 2011; Sheehan \& Foss, 2007). However, despite the growing importance and complexity of this issue, relatively limited attempts have been made (Ketkar \& Sett, 2010; Wright, McMahan, \& McWilliams, 1994).

Overall, the purpose of this paper is therefore to present a conceptual framework to unveil how diverse HRM practices affect firm performance by drawing attention to the complex interplay of contextual factors influencing this relationship. In doing so, through critical review of different strands of literature was carried out to comprehend diverse aspects of this complex relationship. Throughout the multi-level mediation, employee work effort-job performance link (effortperformance link) was adopted in providing an explicit explanation. However, it has been paid less attention in strategic HRM research whereas it has been a well-established linkage in job design, job satisfaction, and job characteristics literature. Further, literature suggests that managerial factors, firmspecific factors, and external context-related factors of the firm play a central role in this relationship. Accordingly, Figure I presents the proposed framework and the sections that follow from Pillar I to Pillar VI justify the configurations. The proposed framework of this paper generates new insights on the nature of the HRM practices-firm performance relationship resulting great implications for theory and practice.

Accordingly, this paper is organized into four major sections. First, it critically reviews empirical research on the multi-level mediation of HRM practices-firm performance relationship since it is the centre-stage of this paper. Second, the theoretical foundation in relation to the proposed framework is reviewed. Third, the proposed conceptual framework is presented. Finally, the implications of the proposed framework and areas for further development of this framework are discussed.

\section{Review of Literature}

With the aim of producing a quality work, 137 journal articles have been reviewed for the purpose of this paper. Most importantly, articles published in the English language have been taken into consideration in order to facilitate assure international readership. All articles referred herein were published during 1990 to 2013 whilst the majority of the articles were published during $2000-2013$. Review of different strands of literature has been a major focus in this endeavour in order to well support the arguments.

\subsection{Impact of HRM Practices on Firm Performance: A Multi-Level Mediation}

A great volume of empirical studies have shown the impact of HRM practices on firm performance through employee work outcomes. These empirical explanations up to now are often based upon the mediation through the more abstract and general heading of "HRM outcomes" (Boselie, Paauwe, \& Jansen, 2001; Paauwe \& Richardson, 1997). The general norm behind such 
single-level mediation is, on one hand, it is simple and easy to analyse; on the other hand, it is ambiguous and difficult to understand the exact process of value creation (Guest, 2011). On the contrary, multi-level mediation incorporates multiple levels of the intervening linkage to explain the sequential process of value addition. Thus, the multi-level mediation is comprehensive as it tightly links HRM practices and firm performance through intervening causes and effects at some distinctive stages (i.e. attitudinal, behavioural, and performance outcomes). As a result, impact of HRM practices on firm performance could be observed progressively through each stage (Guest, 1997). Therefore, in order to establish clearer articulation of the HRM-firm performance relationship, researchers have to define effective number of convincing stages in ways to unveil the unclear relationship between HRM practices and firm performance.

However, to date, limited attention has been paid on explaining the impact of HRM practices on firm performance using multi-level mediation of employee work outcomes. In fact, HRM practices and firm performance are too remote constructs to be linked directly (Guest, 2011). The direct or abstract relationship between HRM practices and firm performance may not provide sufficient understanding of the SHRM phenomenon (Delery, 1998; Dyer \& Reeves, 1995; Becker \& Gerhart, 1996; Guest, 1997). The specific form of this relationship is therefore still on debate (Edgar \& Geare, 2009; Priem \& Butler, 2001; Sheehan \& Foss, 2007).

\section{Prior Studies}

Despite the decades of rigorous research efforts into HRM practices-firm performance relationship, there is still little understanding of the mediating mechanisms through which HRM practices influence firm performance (Boselie et al., 2005; Edgar \& Geare, 2009; Oladipo \& Abdulkadir, 2011; Paauwe, 2009). According to Hope-Hailey, Farndale, and Truss (2005, p. 50), the primary issue in developing conceptual models on this relationship is 'which variables should be included in making the step from HRM to firm performance'. However, in response to recent calls for comprehensive multi-level mediating frameworks, it was noted that some HRM researchers have developed rather similar frameworks for understanding this relationship (e.g. Jiang et al., 2012; Katou, 2012; Ketkar \& Sett, 2010; Paul \& Anantharaman, 2003; Purcell \& Hutchinson, 2007). In summary, the most widely used intervening variables of these frameworks were employees' skills, attitudes, and behaviours at work. For instance, Jiang et al. (2012) explained three systems of HRM practices (skill, motivation, and opportunity-enhancing practices) relate to firm's financial outcomes by influencing human capital and employee motivation as well as voluntary turnover and operational outcomes in sequence. Katou (2012) evidenced HRM policies have a positive effect on organizational performance through employee attitudes (satisfaction, commitment, motivation) and employee behaviours (absences, turnover, disputes) in sequence. In a similar vein, Purcell and Hutchinson (2007) also argue that HRM practices first affect on employee attitudes and in turn employee behaviour to enhance unit-level outcomes. Ketkar and Sett (2010) also found HRM practices as a system that affect firm-level HR outcomes through behavioural flexibility of the employees. Paul and Anantharaman (2003) showed the influence of HRM practices on operating performance and financial performance through some skill-related, attitudinal, and behavioural outcomes such as employee competence, teamwork, organizational commitment, and customer orientation. According to Sudin (2004), HRM practices-firm performance relationship is mediated through human resources characteristics such as Knowledge, Skills, and Abilities (KSAs), motivation, and empowerment. McBain (2004) agreed that HRM practices-firm performance relationship is largely indirect and 
complex, and HRM practices may lead to higher firm performance through the development of valuable employee-based resources.

In sum, these linkages signify HRM as one of the most important functions of an organization that is capable of developing firm's human capital pool for effective implementation of firm's strategies to achieve higher firm performance. In favour, researchers show human capital losses (due to voluntary turnover) adversely affect on organizational performance (Shaw et al., 2013). Therefore, linking HRM and firm performance through multi-level mediation of employee work outcomes has been a realistic approach since employees are the direct recipients of HRM services and employee performance has been the direct source of form performance. However, the adoption of employee effort-performance linkage in contrast to the traditional link of employee skills, attitudes, and behaviours in different stages provides a practical view of this relationship. This is because the multi-level mediation proposed in this paper has integrated employee skills, attitudes, and behaviours to derive employee work effort based on the general consensus that they cannot be observed separately in sequential stages.

\subsection{Theoretical Foundation on HRM Practices - Firm Performance Relationship}

SHRM has been largely criticized for lacking solid theoretical foundation to explain the HRM practices-firm performance relationship (Fleetwood \& Hesketh, 2008; Guest, 2011). This is in fact indirect and very complex relationship (McBain, 2004) and thus one particular theory is unable to map the whole picture (Bong, 1996). Therefore, SHRM researchers have drawn theoretical insights from various disciplines to support this phenomenon (e.g. Becker \& Huselid, 1998; Boselie et al., 2005; Gerhart, 2005; Jackson \& Schuler, 1995; Katou \& Budhwar, 2009; Paauwe, 2009; Panayotopoulou \& Papalexandris, 2004; Snell \& Youndt, 1995; Tzafrir, 2006; Wright \& McMahan, 1992; Wright \& Snell, 1991; Youndt et al., 1996). In line with those scholarly opinions, the theoretical foundation of the proposed framework has been discussed in the following sections. In this effort, first, three prescriptive normative theories supporting the proposed framework and then some macrolevel strategic theories for better underpinning the specific aspects of the proposed framework have been taken into consideration.

\section{Normative Theoretical Perspectives}

The contribution of SHRM to firm performance can be theorized under three major theoretical perspectives namely, the universalistic, contingency, and configurational perspectives (Delery \& Doty, 1996). These perspectives can be considered individually or as a joint approach (Camelo, Martin, Romero, \& Valle, 2004). The universalistic perspective draws direct relationships between HRM practices and firm performance implying that "greater use of specific employment practices will always result in better (or worse) organizational performance" (Delery \& Doty, 1996, p. 806). The contingency perspective implies vertical fit that is the link between firm's HRM practices and internal and external contexts of organizations and how these HRM practices relate to firm performance (Schuler \& Jackson, 2005). The configurational perspective is guided by horizontal fit that implies HRM practices are generally working together as systems than working individually. However, all HRM practices are not equally important to achieve higher firm performance (Kehoe \& Wright, 2010) and they do not always influence equally on firm performance as they are sensitive to the variations of the organizational context (Schuler \& Jackson, 2005). Also, in practice, different sets of HRM practices are working in association with each other than working in isolation, which are additive, mutually overlapping, reinforcing, and synergistic (Arthur, 1994; Huselid, 1995; MacDuffie, 1995). 
As a result HRM practices are socially complex, causally ambiguous, path dependent, and thus not easily imitable (Becker \& Huselid, 1998; Collis \& Montegomery, 1995; Thompson \& Heron, 2005). Therefore, this paper has conceptualized a macro-level framework that requires a joint theoretical approach, which is scarce in the literature. However, some empirical researchers have linked HRM systems to different firm strategies and their association to firm performance (Arthur, 1994; Huselid, 1995; MacDuffie, 1995). Yet, the influence of other contextual factors on HRM systems have been paid less attention, thus, do not adopt a more holistic view.

\section{Strategic Theories: $R B V$}

In fact, theory-based empirical explanations are of great significance to enhance the credibility of HRM-firm performance relationship (Fleetwood \& Hesketh, 2006). Therefore, in relation to the proposed framework, some macro-level theories have been taken into consideration. The Resource Based View (RBV) of the firm (Barney, 2001; Wright, Dunford, Snell, 2001) was chosen because it has been the most often used and thus very popular framework in the strategic HRM literature (Ismail, Omar, \& Bidmeshgipour, 2010; Wright et al., 2001). The core idea behind the RBV is that firms with unique resources may enjoy superior performance than those who do not (Barney, 1991).

Literature shows that "it provides a theoretical bridge between HRM and firm competitiveness" (Holtbrugge, Friedmann, \& Puck, 2010, p. 441) and "a compelling explanation for why HR practices lead to competitive advantage" (Wright et al., 2001, p. 706). According to Wright et al. (2001), the application of RBV to strategic HRM research has numerous justifications. For instance, one idea is human capital pool of a firm as a source of competitive advantage (Wright et al., 1994). Another justification is HRM practices possess the potential of achieving competitive advantage (Lado \& Wilson, 1994). According to Holtbrugge et al. (2010), the logic behind this application is that "HR practices constitute a complex and interdependent system that cannot be copied easily. .... Hence, value, uniqueness, and inimitability are argued to enhance HRM efficiency" (p. 442), that in turn provide the basis for sustained competitive advantage. Recent strategic HRM researchers suggest that HRM practices are a tool to enhance the key elements of sustained advantage found in the RBV (Shaw et al., 2013).

Delery and Shaw (2001) opined that firms can invest on different HRM practices such as training, sophisticated selection, financial incentives and other HRM practices to increase the value, rareness, non-substitutability, and inimitability of the human capital pool. Therefore, HRM practices in high investment organizations act as a tool of building the workforce that creates competitive advantage (Delery \& Shaw, 2001). In essence, RBV researchers have emphasized both human capital pool and investments in HRM practices can substantially and positively influence firm performance (Hitt, Bierman, Shimizu, \& Kochhar, 2001). In favour to this notion, recent resource-based literature point out firms where HRM investments are high may lower the human capital losses (through voluntary turnover) that lead to higher firm performance (Shaw et al., 2013). All in all, the current review evidenced that the resource-based reasoning is consistent with the notion that HRM practices become a source of firm performance due to their contribution to the development and maintenance of high quality human capital pool that in turn results various other productive employee outcomes. For instance, job satisfaction, lower employee turnover, lower employee absenteeism etc. which convert HRM practices into firm performance. However, the resource-based model outlined in Barney's original article (1991, p. 112) provides more abstract view of the complex interplay in SHRM. According to the proposed framework, the different pillars/stages in the causality represent different 
resources of Barney's resource classification: organizational resources, human resource, and physical resources. These resources and their core constituents represent bundle of tangible and intangible firm resources that lead to superior performance of the firm. Therefore, the direct linkages from different pillars/stages to firm performance can be well justified as per the RBV. However, when it comes to explain the full complex framework particularly the intervening linkage, RBV has limited contribution.

\section{Theories for Intervening Linkage}

The argument in relation to the intervening linkage of this relationship is productive employee behaviours make the most direct influence on firm performance. This notion is well supported by the behavioural perspective (Wright \& McMahan, 1992) that denotes human behaviour as the mediator between firm's strategy and firm performance. This is much popular as one of the strategic theories of HRM. The primary assumption of this framework is the main purpose of having diverse HRM practices is to elicit and control behaviour of the employees that lead to various outcomes providing benefits to the firm. However, literature show employee behaviour, most importantly the extent to which employees exert at work is earnestly linked with employees' KSAs (Knowledge, Skills, and Abilities), attitudes (such as motivation, commitment, job satisfaction), and opportunity using employee ability, motivation, opportunity (AMO) model (Appelbaum, Bailey, Berg, \& Kalleberg, 2000; Boselie, 2010; Boxall \& Purcell, 2003; Combs, Liu, Hall, \& Ketchen, 2006; Katou \& Budhwar, 2009; Shih, Chiang, \& Hsu, 2006; Sudin, 2004). Therefore, the AMO model is increasingly used to answer the 'black-box' between HRM practices and firm performance. The underlying notion of this model has been firm's HRM practices influence employee ability, motivation, and opportunity to work. As a result, employees discretionary effort would be enhanced that in turn affect firm performance. Further, the form of this link is suggested by the social exchange theory (Zhang \& Jia, 2010). It implies that HRM practices are viewed by employees as organizational commitment towards employees and it is reciprocated back to the organization by employees through positive attitudes and behaviours. However, employees' behavioural intension is guided by reasoned action theory (Southey, 2011; Zawawi, Idris, \& Rahman, 2011). It denotes employee attitudes toward behaviour (individual's overall evaluation to perform the said behaviour) and subjective norm (individual's perception of social pressure to perform or not to perform) predict, explain or influence behavioural intension to perform or not to perform a certain behaviour that in turn predict, explain or influence the actual performance of the said behaviour.

\section{Theories for Contextual Influences}

SHRM researchers have used various theories to support different aspects of contextual influences on effective adoption of HRM. Accordingly, the influence of management-related factors on HRM is theorized using managerial rents model (Castanias \& Helfat, 2001), firm-related factors on HRM using contingency theory (Schuler \& Jackson, 2005), and external context-related factors on HRM is theorized using institutional theory/ institutionalism (Boon, Paauwe, Boselie, \& Hartog, 2009). The managerial rents model implies the premise that managers differ in their capabilities that lead them to undertake different strategic actions resulting different outcomes for organizations. This highlights the importance of managerial capabilities for firm performance. The contingency theory which is also known as 'best-fit' approach implies different organizational principles are appropriate under different environmental circumstances and structural characteristics of the organization. It senses that the effectiveness of a firm's operations depends on its suitable match with an organization's internal and external environments. Also, institutional theory being in line with this notion argues the need of 
legitimacy for an organization to survive. Institutionalization denotes "the processes by which societal expectations of appropriate organizational action influence the structuring and actions of organizations" (Boon et al., 2009, p. 494). Therefore, institutional theory is specifically developed to capture institutional pressures that shape organizational practices including HRM (Boon et al., 2009).

All in all, these theories play an important role in justifying empirical link between HRM practices and firm performance, thus theory-based empirical explanations to this link enhances its credibility, attractiveness, and in turn investment.

\section{Proposed Conceptual Framework}

Gaining insights from the extant theoretical and empirical models, an integrated conceptual framework was developed for the HRM practices-firm performance relationship consisting of six pillars as discussed below (Figure I). The argument behind this framework is the chief strategic goal of any business is higher firm performance through increased unit-level operational performance that depends to a large extent on employee job performance. Employee job performance is the direct outcome of employee work effort and the main purpose of HRM in any firm is to shape employee work behaviour. HRM systems such as employee talent management and employee relationships management are empirically evidenced as important in influencing employee work effort. Overall, HRM and firm performance cannot be assessed in isolation since which are influenced by internal and external contexts of organizations.

\section{Pillar I: Contextual Factors}

SHRM literature emphasises the need of understanding the complex interplay of contextual factors affecting HRM (Aycan, 2005) and firm performance (Singh et al., 2012). Truss (2003) found that "context often served as a constraining factor" for the strategic role of HRM function of the National Health Service in UK (p. 48). Fields, Chan, and Akhtar (2000) noted in relation to their study that "measures of context explain over one-half the variance in HRM strategy" (p. 273). These findings evidence the importance of understanding the influence of different aspects of the context in relation to HRM practices-firm performance relationship.

This paper has hypothesized a great deal of contextual factors under three major categories namely, HR staff capabilities, firm-specific factors, and external context. First, HR staff capabilities such as knowledge, skills, abilities (KSAs) (Chung \& Kang, 2013; Sajeewanie \& Opatha, 2007; Thompson \& Heron, 2005; Truss, 2003), experience (Arulrajah \& Opatha, 2012; Sajeewanie \& Opatha, 2007), attitudes, leadership (Singh et al., 2012; Truss, 2003), and social networks with intra and inter organizational members such as top management, line management, competitors, and employees (Chung \& Kang, 2013; Thang \& Quang, 2005; Truss, 2003) as very important for effective adoption of HRM practices in any firm. HR staff as the key player of the HRM function needs to be competent, possess positive attitudes towards HRM activities, possess good experience of the HRM function and related issues and challenges, possess effective leadership to deal with matters arising within and outside the HRM department primarily for effective human resource planning in any firm. Moreover, primarily, HR staff's social networks with the top management help adequate allocation of resources, with the line management help accurate implementation of HRM practices, and HR staff's social support/networks with the competitors and employees provide valuable inputs for effective designing and implementation of HRM policies and practices. Second, the proposed framework integrates firm-specific factors such as capital intensity (Katou \& Budhwar, 2007), R\&D intensity 
Figure 1: Multi-Level Mediation of HRM - Firm Performance Relationship

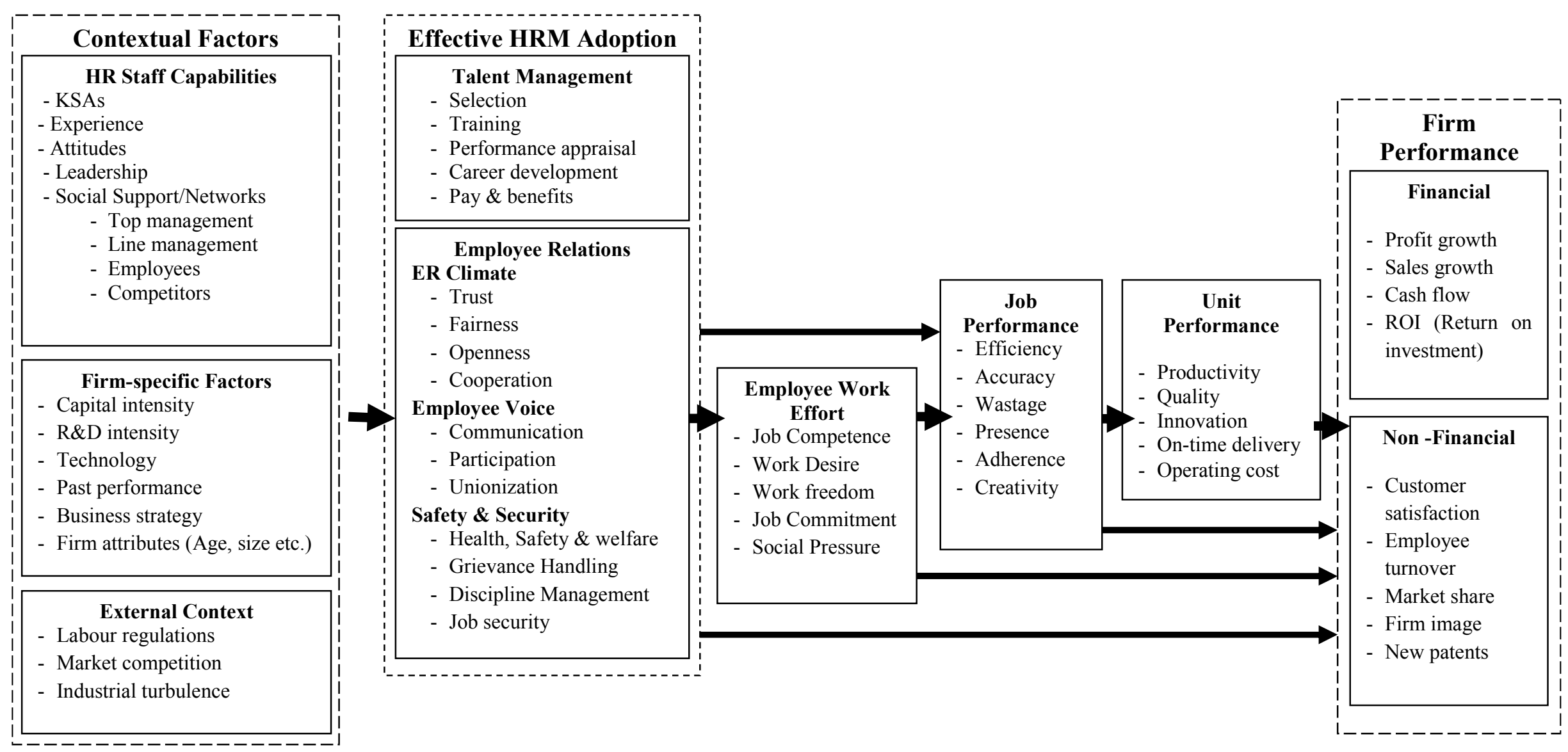


(Singh et al., 2012), technology (Jackson \& Schuler, 1995; Kaufman, 2010; Kotha \& Swamidass, 2000), business strategy (Ding \& Akhtar, 2001; Jackson \& Schuler, 1995; Kaufman, 2010), past performance (Katou, 2012; Shih et al., 2006; Singh et al., 2012), firm attributes (Age, size etc.) (Aycan, 2005; Ding \& Akhtar, 2001; Fields et al., 2000; Kaufman, 2010; Shih et al., 2006) as major determinants of HRM because these factors determine the capacities and complexities of the context which in turn determine the demand and choice for HRM. For instance, the demand for HRM increases with firm size due to greater difficulty in coordinating large groups of employees (Kaufman, 2010). Finally, it is considered external/institutional context particularly related to competitive, coercive, and mimetic isomorphism such as market competitiveness (Boon et al., 2009; Kaufman, 2010; Singh et al., 2012), government labour regulations (Boon et al., 2009; Jackson \& Schuler, 1995; Kaufman, 2010; Singh et al., 2012), and industrial uncertainty/ turbulence (Boon et al., 2009; Jackson \& Schuler, 1995; Shih et al., 2006) as influential for HRM adoption because these factors lead to tensions, uncertainty and pressure in firms that shape HRM practices (Bjorkman \& Budhwar, 2007; Boon et al., 2009; Jackson \& Schuler, 1995; Jaffari, Saleem, \& Abideen 2011; Tsai, Edwards, \& Sengupta, 2010).

It is also found these contextual factors as direct determinants of firm performance (Andersen, 2011; Acquaah \& Chi, 2007; Fabi, Lacoursiere, Raymond, \& St-Pierre, 2010; Phua, 2006; Singh et al., 2012; Welter, Bosse, \& Alvarez, 2013), yet limited attention has been paid so far to integrate these factors in one single framework. Hence, this paper integrates such influences in one single framework to provide more realistic view of this relationship.

\section{Pillar II: Effective HRM Adoption}

The aim of effective adoption of HRM in any firm is to create a high performing workforce. The review of literature evidenced that employee development and employee involvement HRM practices are highly important in creating high performance work climate (Boselie, 2010). Thus, similarly, the current framework proposes two empirically driven HRM systems namely, talent management system and employee relationships management system for effective management of employees towards higher firm performance. Without talents employees would not be able to work effectively and efficiently because talents are a must to deal with issues, challenges, and modern innovations of the workplace. Therefore, it is a widely held premise that "effective management of human capital, not physical capital, may be the ultimate determinant of organizational performance" (Youndt et al., 1996, p. 836). In support, Youndt and colleagues show a direct relationship between human-capital enhancing HRM system and operational performance of a firm. Having considered the overall process of managing employees' talent at work such as attract, develop, and retain/manage talented employees, the talent management HRM system includes employee selection, training, performance appraisal, career development, and pay and benefits practices (Areiqat, Abdelhadi, \& Al-Tarawneh, 2010; Hughes \& Rog, 2008; Youndt et al., 1996).

However, organizations may not achieve higher performance only with employee talents, which further requires developing employee attitudes, norms, and opportunities (Appelbaum et al., 2000; Boselie, 2010; Boxall \& Purcell, 2003; Combs et al., 2006; Sudin, 2004). Thus, paying adequate considerations on the requirement for appropriate relationships with employees, employee relations HRM system (Katou \& Budhwar, 2009) includes various practices. For instance, employee relations (ER) climate management (trust, fairness, openness, and cooperation) (Abdulkadir, 2012; Collins \& 
Smith, 2006; Ngo, Lau, \& Foley, 2008), employee voice management (communication, participation, and unionization) (Katou, 2012), and employee safety and security management (health, safety and welfare, grievance handling, discipline management, and job security related practices) (Katou \& Budhwar, 2007). In relation to this configuration, it is found that past researchers had considered ER climate as an outcome of firm's HRM practices (Collins \& Smith, 2006). Having considered the extant literature, four dimensions of ER climate have been proposed namely, trust, fairness, openness, and cooperation between managers and employees. These are very important HRM practices for enhancing employee effort at work since they increase employee attachment to the workplace (Abdulkadir, 2012). However, it is important to keep in mind that although two HRM systems are considered in the proposed framework, it is practically very difficult to segregate HRM practices into specific systems since HRM practices to some extent mutually overlapping.

In this relation, the number of HRM practices and how they are designed and implemented determine how far firms can achieve its strategic objectives. Accordingly, it is important to measure the extent to which diverse HRM practices of the firm are designed and implemented effectively than just only quantifying the number (Belcourt, 2001; Guest, 2011; Huselid, Jackson, \& Schuler, 1997). Therefore, this paper suggests the measures of the effective adoption of HRM to be: (1) availability of a formal system, (2) use of appropriate tools and techniques, (3) employers and/or employees' knowledge of the subject, (4) speedy execution, (5) fairness, (6) accurate implementation of the intended practices, (7) regular evaluation, (8) revision, and (9) record keeping based on the review of literature (Ali \& Opatha, 2008; Gamage \& Hewagama, 2007; Sels, Winne, Delmotte, Maes, Faems, \& Forrier, 2006; Serasinghe \& Opatha, 2007).

\section{Pillar III: Employee Work Effort}

Literature evidence that the nature of HRM practices-firm performance relationship is largely indirect (McBain, 2004) although direct relationships have been drawn statistically. Therefore, a practically justifiable mediating linkage is essential to convince how HRM practices are linked with firm performance. In the proposed multi-level mediation, employee work effort: the extent of hard work exerted by an employee towards completing a task (Brown \& Leigh, 1996), is a very comprehensive mediator to link between HRM practices and firm performance. Scholars point out employee outcomes as the direct outcomes of how firms manage their workforce (Pfeffer, 2005) and in turn employees' productive outcomes have been the direct source of firm performance (Barney \& Wright, 1998; Youndt et al., 1996). Therefore, past studies proposed that employee work effort can mediate the HRM practices-firm performance relationship (McClean \& Collins, 2011). Further, previous studies have shown that employee work effort is a function of employee ability, motivation, and opportunity to perform (Appelbaum et al., 2000; Boxall \& Purcell, 2003; Doty \& Delery, 1997; Shih et al., 2006). Moreover, in the marketing literature, employee job commitment is identified as a direct influence to employees' effort at work (Ingram, Lee, \& Skinner, 1989). In the goal setting literature, it is identified that employee commitment increases the effort an individual exerts toward achieving the goal (Lee, Keil, \& Kasi, 2012). Waiganjo, Mukulu, and Kahiri (2012) noted that "In most firms today, it is the employees' skills and commitment that create competitive advantage for an organization" (p. 64). Researchers also show HRM practices control employee behaviour by giving them some pressure to work (Arthur, 1994). Therefore, blending those insights, the proposed framework suggests employee work effort is a function of employees' ability to work (job competence), desire to work (work desire), freedom to work (work freedom), commitment to work (job commitment), and social influence to work (social pressure). 
Job Competence: The term job competence has been synonymously used to denote ability, capability, knowledge and skills necessary for employees to perform successfully at work (Wright et al., 1994; Wright \& Snell, 1991). Therefore, Inyang (2011) emphasises that the development of employee competence is a core responsibility of a firm's HRM function, which avoids human resource obsolescence and leads to higher performance. The review of literature suggests that an effective HRM system must have variety of adequate practices to attract, develop, and retain competent employees for better attainment of organisational goals. Previous studies have shown that selection, training, performance appraisal, and pay and benefits practices as main HRM practices that provide opportunities and motivation for the employees to develop firm-specific skills through knowledge sharing (Delaney \& Huselid, 1996; Jiang et al., 2012; Kehoe \& Wright, 2010; Subromony, 2009; Wright, McCormick, Sherman, \& McMahan, 1999).

Work Desire: $\quad$ Employee desire or motivation to work is an employees' attitudinal outcome, which is a fundamental requirement for employees to engage in discretionary behaviours for the attainment of organizational goals (Appelbaum et al., 2000; Fey, Bjorkman, \& Pavlovskaya, 2000; Wright \& Snell, 1991). A well-motivated human resource has been asserted as a strategic asset of an organization (Inyang, 2011) that mediates HRM practices-firm performance relationship (Fey et al., 2000; Park, Mitsuhashi, Fey, \& Bjorkman, 2003). Therefore, firms invest in diverse HRM practices to motivate their employees (Delaney \& Huselid, 1996; Jiang et al., 2012; Kehoe \& Wright, 2010; Subramony, 2009; Wright et al., 1999). Accordingly, performance appraisal, benefits, career development, job security, health care, and employee involvement are important HRM practices that change employee attitudes and arouse their desire to work harder and smarter.

Work Freedom: Work freedom can be interchangeably termed as opportunity to participate /perform (Appelbaum et al., 2000) or empowerment (Subramony, 2009; Sudin, 2004). It determines the extent to which employees exert at work because without adequate opportunity employees would not be able to fully utilize their potential although they are skilled and motivated (Bailey, Berg, \& Sandy, 2001). There are diverse HRM practices such as employee involvement and participation, formal grievance and complaint processes, information sharing practices, reward systems, and open communication practices that provide necessary support and avenues for employees to work with their full potential (Arthur, 1994; Jiang et al., 2012; Subromony, 2009).

Job Commitment: Any job consists of a set of goals or targets to achieve. The goal setting literature defines commitment as "an individual's determination to achieve a goal" (Lee et al., 2012, p. 61) and identified it as an element of employee work effort. The reasoning behind that inclusion is committed employees can be trusted to use their discretion in order to carry out job tasks in ways that are consistent with organizational goals. The marketing literature also defines job commitment as "high involvement in work activities" (Ingram et al., 1989, p. 26), thus becomes a core constituent of employee work effort. Therefore, firms invest on HRM practices to enhance employee commitment since committed employees similar to competent and motivated employees are a real asset for any organization. Previous studies have shown that incentives and rewards, training and development, pay and benefits, participation practices, and unionization as commitment-enhancing HRM practices. These HRM practices enhance desired employee attitudes by forging psychological links between organisational and employee goals that in turn enhance desired employee work behaviours (Arthur, 1994; Collins \& Smith, 2006; Katou \& Budhwar, 2007; MacDuffie, 1995; Snell \& Dean, 1992; Youndt et al., 1996). 
Social Pressure: Social pressure is an extrinsic factor (not within employees) that plays a central role in influencing the extent to which employees exert at work. Employees tend to perform well when there is pressure to work from their social environment since if not, pressure diminishes one's social recognition. There are numerous sources of pressure, such as customs, requirements, legislation, enforcements etc in the working environment. Therefore, some SHRM researchers have adopted 'social structure' along with KSAs, motivation, and empowerment to link high performance work practices and organizational performance (Combs et al., 2006). However, there is relatively very less use of this factor at this stage in SHRM research. Therefore, the proposed framework suggests social pressure as an influential dimension of employee work effort blending insights from reasoned action theory.

\section{Pillar IV: Job Performance}

Job performance refers to the level of achievement of business and social objectives and responsibilities from the perspective of the judging party (Hersey \& Blanchard, 1993). Accordingly, job performance is a direct outcome of employee work effort and thus employee effort-performance link is well recognized in the goal setting, job design, and job characteristics models (Brown \& Leigh, 1996; Menguc, 1996; Piccolo, Greenbaum, Hartog, \& Folger, 2010; Yeo \& Neal, 2004). Yet, effortperformance link is so far received relatively scant empirical attention in linking HRM practices and firm performance. However, this is in fact an apparent link since when firms offer fair combination of HRM practices, employees apparently develop positive attitudes towards the firm and may exhibit high levels of discretionary effort at work. When employees exhibit high levels of discretionary effort at work, they actively engage in broader work roles (Khan, 1990) and exert as hard as they can with intensity and energy (Brown \& Leigh, 1996). It then results in increased job performance of the employees. Therefore, it can be argued that this link can work as an effective mediating mechanism in HRM practices-firm performance relationship since higher employee job performance is a direct source of operating performance of a firm (Ketkar \& Sett, 2010).

Past studies point out that job performance can be evaluated variously in terms of the output of an employee (Becker \& Huselid, 1998; Delaney \& Huselid, 1996; Ketkar \& Sett, 2010; Yousef, 1998). Therefore, this paper proposes six dimensions to measure employee job performance in a particular line, unit or a department, namely, accuracy (non-defectiveness of products), efficiency (speed of production), presence (not being absent), adherence (level of employees' adherence to the work ethics/policies of the firm), wastage (level of wastage of materials in doing the job) and creativity (suggesting creative ideas at work).

\section{Pillar V: Unit Performance}

A tight linkage is instrumental to justify how and why the association between HRM practices and firm performance exist as there is no specific theory for this purpose (Guest 1997, 2011). Therefore, in order to avoid causal gap of this linkage, it is proposed to assess operating performance of each unit (unit performance) in relation to productivity (amount of units), quality, innovation, ontime delivery, and operating cost (Paul \& Anantharaman, 2003). However, it is very difficult to propose a set of performance measures since which is "a company-dominated criterion" (Guest, 1997, p. 266). Therefore, this paper has proposed multiple criteria consistent with the 'balanced scorecard' (Kaplan \& Norton, 2005) to measure unit performance. It emphasizes the need to concentrate different aspects in order to provide a broader view of unit level performance. As Guest (1997) emphasized, it is needed to establish multiple linkages between employee job level and firm level measures to ensure 
the causal chain. For instance, efficiency may increase productivity and on-time delivery which may affect profit, customer satisfaction, and market share. Accuracy may increase quality which may increase customer satisfaction, market share, firm image, and profit. Wastage may increase operating cost and reduce productivity that in turn increase employee turnover and reduce profit. Therefore, the proposed model is of substantial importance for credible explanation of the HRM practices-firm performance relationship since "HRM has been weak in this area" (Guest, 1997, p. 267). Therefore, researchers are still searching for some answers for this link (Guest, 2011).

\section{Pillar VI: Firm Performance}

Firm performance is a result of interplay between various internal and external factors of the firm (Singh et al., 2012). Hence, scholars point out firm performance should be represented by both financial and non-financial aspects (Bititci, 1994; Tangen, 2004). The financial performance refers to the economic status of a firm such as profitability, sales growth, return on assets etc. (Fabling \& Grimes, 2010; Huselid, 1995; Huselid, et al, 1997; Snell \& Youndt, 1995), and all activities of a firm are ultimately associated with its financial status either directly or indirectly. Hence, previous studies reveal that financial indicators as a whole are the most frequently used in measuring firm performance (Gomes, Yasin, \& Lisboa, 2007). The non-financial performance is represented by diverse aspects such as competitiveness, effectiveness (Antony \& Bhattacharyya, 2010), new products, responsive supply (Kaplan \& Norton, 2005) customer satisfaction (Gomes et al., 2011), market share, employee retention (Jusoh, Ibrahim, \& Zainuddin, 2008), firm image (Bae \& Lawler, 2000; Moideenkutty, AlLamki, \& Murthy, 2011) etc.

Based on the current review of literature, the proposed framework in Figure 1 integrates a diverse set of financial (such as profit growth, sales growth, cash flow, and return on investments) and nonfinancial firm performance dimensions (such as employee turnover, customer satisfaction, market share, firm image, and new patents).

\section{Testing the Proposed Framework}

Having considered the critical review of theoretical and empirical literature in the previous sections, the complex relationship between effective HRM and firm performance has been conceptualized as shown in Figure I. Consequently, it is important to bear in mind that testing the proposed conceptual framework is not an easy task. Practically, it requires a lot of effort, time, and money as it involves a large number of variables to measure. It is obvious that HRM-firm performance relationship is not an isolated phenomenon. Instead, it has been influenced by and linked with diverse aspects.

However, in testing this framework, it is required to formulate a set of prepositions in line with the hypothesized linkages as depicted in Figure I. In order to generalize the proposed framework, it is required to test this framework in different contexts through different sources and methods of data. Most importantly, since the proposed framework is rather complex, it is required to pay attention on confirmatory factor analysis through structural equation modelling using software packages like AMOS, SmartPLS etc. in order to assure the overall model-fit. 


\section{Implications for Practice and Research}

The conceptual framework proposed in this paper (Figure 1) has great implications for practice and research due to its significant refinements to existing frameworks. Most importantly, there are three main implications for practice. First, this framework addresses the process 'black-box' issue between HRM practices and firm performance by integrating employees' productive outcomes in a more comprehensive multi-level mediation form. In so doing, the framework shows how HRM practices may influence the core constituents of employee work effort and its association with employee job performance and in turn unit performance to fill the gap in the process of value creation. Thus, this proposed framework assures the credibility of this relationship bridging the gap between theory and practice. It ultimately increases practitioners' attention on effective HRM investment towards higher firm performance instead of ad hoc and opportunistic adoption of HRM and in turn influences employee attitudes, healthy working climate, and quality of life.

Second, this framework highlights the central role of contextual factors for effective adoption of HRM. Thus, it encourages practitioners towards the active management of these conditions giving them a challenging role to play than their traditional administrative duties. The framework supports the notion that effective HRM is not a one man show, instead it is a collective influence of managerial, firm-specific, and external influences. According to the true picture of this relationship, it is unreal to omit the context where the HRM function operates since there is a direct relationship between the context and the function.

Third, HRM is in fact a costly investment even though the inconclusive empirical findings on this relationship has led to the idea that HRM is just a cost. Therefore, this framework shows the importance of number of HRM practices, particularly, ER climate than a concrete set of traditional HRM practices in contemporary firms. Further, this shows synergetic effect of HRM systems against individual HRM practices working in isolation. Firms can therefore organize their HRM activities to manage their employees more effectively for better results. Overall contribution of this proposed framework will enhance the credibility of this relationship.

The proposed conceptual framework suggests three major implications for research. First, this framework brings substantial contribution to resource-based literature since this framework substantially details the holistic view of HRM practices-firm performance relationship, which so far has limited frameworks in a practice-relevant form. Second, most importantly, this framework guides future researchers to open the 'black-box' of this relationship from an integrated view of employee outcomes in contrast to the sequential link of employee skills - attitudes - behaviour. We propose employee skills and attitudes as core constituents of employee behaviour and not separately observable. Third, the proposed framework guides future researchers to make a good choice of contextual factors, HRM practices, and various dimensions for better analysing this relationship whilst discouraging narrow and static focus on them. However, future researchers could incorporate employee, firm and industry specific characteristics as moderators and extend HRM practices-firm performance relationship into a moderated-mediation framework.

\section{References}

Abdulkadir, A. D. (2012). Strategic human resource management and organizational performance in the Nigerian insurance industry: The impact of organizational climate. Business Intelligence Journal, 5(1), 8-20. 
Acquaah, M., \& Chi, T. (2007). A longitudinal analysis of the impact of firm resources and industry characteristics of firm-specific profitability. Journal of Management and Governance, 11(3), 179-213. doi: 0.1007/s10997-007-9031-8

Ali, M. A. M. H., \& Opatha, H. H. D. N. P. (2008). Performance appraisal system and business performance: An empirical study in Sri Lankan apparel industry. Sri Lankan Journal of Human Resource Management, 2(1), 74-90.

Amit, R., \& Shoemaker, P. J. H. (1993). Strategic assets and organizational rent. Strategic Management Journal, 14, 33-46.

Andersen, J. (2011). Strategic resources and firm performance. Management Decisions, 49(1), 87-98.

Antony, J. P., \& Bhattacharyya, S. (2010). Measuring organizational performance and organizational excellence of SMEs - part 2: An empirical study on SMEs in India. Measuring Business Excellence, 14(3), 42-52.

Appelbaum, E., Bailey, T., Berg, P., \& Kalleberg, A. (2000). Manufacturing advantage: Why high performance work systems pay off. Ithaca, NY: Cornell University Press.

Areiqat, A. Y., Abdelhadi, T., \& Al-Tarawneh, A. (2010). Talent management as a strategic practice of human resources management to improve human performance. Interdisciplinary Journal of Contemporary Research in Business, 2(2), 329-341.

Arthur, J. B. (1994). Effects of human resource systems on manufacturing performance and turnover. Academy of Management Journal, 37(3), 670-687.

Arulrajah, A. A., \& Opatha, H. H. D. N. P. (2012). An exploratory study on the personal qualities/characteristics expected by the organizations for key HRM jobs in Sri Lanka. Sri Lanka Journal of Human Resource Management, 3(1), 32-48.

Aycan, Z. (2005). The interplay between cultural and institutional/structural contingencies in human resource management practices. International Journal of Human Resource Management, 16(7), 1083-1119.

Bae, J., \& Lawler, J. J. (2000). Organizational and HRM strategies in Korea: Impact on firm performance in an emerging economy. Academy of Management Journal, 43(3), 502-517.

Bailey, T., Berg, P., \& Sandy, C. (2001). The effect of high-performance work practices on employee earnings in the steel, apparel, and medical electronics and imaging industries. Industrial and Labor Relations Review, 54(2A), 525-543.

Barney, J. B. (1991). Firm resources and sustained competitive advantage. Journal of Management, $17(1), 99-120$.

Barney, J. B. (2001). Is the resource-based "view" a useful perspective for strategic management research? Yes. Academy of Management Review, 26(1), 41-56.

Barney, J. B., \& Wright, P. M. (1998). On becoming a strategic partner: The role of human resources in gaining competitive advantage. Human Resource Management, 37(1), 31-46.

Becker, B., \& Gerhart, B. (1996). The impact of human resource management on organizational performance: Progress and prospects. Academy of Management Journal, 39(4), 779-801.

Becker, B. E., \& Huselid, M. A. (1998). High performance work systems and firm performance: A synthesis of research and managerial implications. Research in Personnel and Human Resource Management, 16, 53-101.

Becker, B., \& Huselid, M. (2006). Strategic human resources management: Where do we go from here? Journal of Management, 32(6), 898-925.

Belcourt, M. (2001, January/February). Measuring and managing the HR function: A guide for boards. Ivey Business Journal, 35-39.

Bititci, U. S. (1994). Measuring your way to profit. Management Decision, 32(6), 16-24. 
Bjorkman, I., \& Budhwar, P. (2007). When in Rome? - Human resource management and the performance of foreign firms operating in India. Employee Relations, 29(6), 595-610.

Bong, M. (1996). Problems in academic motivation research and advantages and disadvantages of their solution. Contemporary Educational Psychology, 21(2), 149-165.

Boon, C., Paauwe, J., Boselie, P., \& Hartog, D. D. (2009). Institutional pressures and HRM: Developing institutional fit. Personnel Review, 38(5), 492-508.

Boselie, P. (2010). High performance work practices in the health care sector: A Dutch case study. International Journal of Manpower, 31(1), 42-58.

Boselie, P., Dietz, G., \& Boon, C. (2005). Commonalities and contradictions in HRM and performance research. Human Resource Management Journal, 15(3), 67-94.

Boselie, P., Paauwe, J., \& Jansen, P. (2001). Human resource management and performance: Lessons from the Netherlands. International Journal of Human Resource Management, 12(7), 11071125 .

Boxall, P., \& Purcell, J. (2003). Strategy and human resource management. Hampshire, England: Palgrave-Macmillan.

Brown, S. P., \& Leigh, T. W. (1996). A new look at psychological climate and its relationship to job involvement, effort, and performance. Journal of Applied Psychology, 81(4), 358-368.

Camelo, C., Martin, F., Romero, P. M., \& Valle, R. (2004). Human resources management in Spain: Is it possible to speak of a typical model?. International Journal of Human Resource Management, 15(6), 935-958.

Castanias, R. P., \& Helfat, C. E. (2001). The managerial rents model: Theory and empirical analysis. Journal of Management, 27(6).

Chung, H. S., \& Kang, S. C. (2013). Sources of HR department power: Scale development and validation. Seoul Journal of Business, 19(2), 95-126.

Colbert, B. A. (2004). The complex resource-based view: Implications for theory and practice in strategic human resource management. Academy of Management Review, 29(3), 341-358.

Collins, C. J., \& Smith, K. G. (2006). Knowledge exchange and combination: The role of human resource practices in the performance of high-technology firms. Academy of Management Journal, 49(3), 544-560.

Collis, D. J., \& Montgomery, C. A. (1995). Competing on resources. Harvard Business Review, July August, 118-128.

Combs, J., Liu, Y., Hall, A., \& Ketchen, D. (2006). How much do high-performance work practices matter? A meta-analysis of their effects on organizational performance. Personnel Psychology, 59, 501-528.

Delaney, J. T., \& Huselid, M. A. (1996). The impact of human resource management practices on perceptions of organizational performance. Academy of Management Journal, 39(4), 949-969.

Delery, J. E. (1998). Issues of fit in strategic human resource management: Implications for research. Human Resource Management Review, 8(3), 289-309.

Delery, J. E., \& Doty, D. H. (1996). Modes of theorizing in strategic human resource management: Tests of universalistic, contingency, and configurational performance predictions. Academy of Management Journal, 39(4), 802-835.

Delery, J. E., \& Shaw, J. D. (2001). The strategic management of people in working organizations: Review, synthesis, and extension. Research in Personnel and Human Resource Management, 20, 165-197. 
Ding, D. Z., \& Akhtar, S. (2001). The organizational choice of human resource management practices: A study of Chinese enterprises in three cities in the PRC. International Journal of Human Resource Management Practices, 12(6), 946-964.

Doty, D. H., \& Delery, J. E. (1997). The importance of Holism, Interdependence, and Equifinality assumptions in high performance work systems: Toward theories of the high performance work force. Paper presented at the annual meetings of the Academy of Management, Boston, MA.

Dyer, L., \& Reeves, T. (1995). Human resource strategies and firm performance: What do we know and where do we need to go?. International Journal of Human Resource Management, 6(3), 656-670.

Edgar, F., \& Geare, A. (2009). Inside the "black box" and "HRM". International Journal of Manpower, 30(3), 220-236.

Fabi, B., Lacoursiere, R., Raymond, L., \& St-Pierre, J. (2010). HRM capabilities as a determinant and enabler of productivity for manufacturing SMEs. Human Systems Management, 29, 115-125.

Fabling, R., \& Grimes, A. (2010). HR practices and New Zealand firm performance: What matters and who does it?. The International Journal of Human Resource Management, 21(4), 488-508.

Fey, C. F., Bjorkman, I., \& Pavlovskaya, A. (2000). The effect of human resource management practices on firm performance in Russia. International Journal of Human Resource Management, 11(1), 1-8.

Fields, D., Chan, A., \& Akhtar, S. (2000). Organizational context and human resource management strategy: A structural equation analysis of Hong Kong firms. International Journal of Human Resource Management, 11(2), 264-277.

Fleetwood, S., \& Hesketh, A. (2006). HRM-performance relationship: Under theorized and lacking explanatory power. International Journal of Human Resource Management, 17(12), 1977-1993.

Fleetwood, S., \& Hesketh, A. (2008). Theorizing Under-theorization in Research on the HRMPerformance Link. Personnel Review, 37(2), 126-144.

Gamage, P. N., \& Hewagama, G. V. (2007). An empirical study of grievance settlement and labour management relationship of apparel industry in Sri Lanka. Kelaniya Journal of Human Resource Management, 2(2), 170-186.

Gerhart, B. (2005). Human resource and business performance: findings, unanswered questions, and an alternative approach. Management Revue, 16(2), 174-185.

Gomes, C. F., Yasin, M. M., \& Lisboa, J. V. (2007). An empirical investigation of manufacturing performance measures utilization-The perspectives of executives and financial analysts. International Journal of Productivity and Performance Management, 56(3), 187-204.

Gomes, C. F., Yasin, M. M., \& Lisboa, J. V. (2011). Performance measurement practices in manufacturing firms. International Journal of Operations and Production Management, 31(1), 5-30.

Grant, R. M. (2001). The resource-based theory of competitive advantage: Implications for strategy formulation. California Management Review, spring 114-135.

Guest, D. E. (1997), "Human resource management and performance: A review and research agenda. International Journal of Human Resource Management, 8(3), 263-276.

Guest, D. E. (2011). Human resource management and performance: Still searching for some answers. Human Resource Management Journal, 21(1), 3-13.

Hersey, P., \& Blanchard, K. H. (1993). Leadership style: Attitudes and behaviours.Englewood Cliffs, NJ : Prentice Hall. 
Hitt, M. A., Bierman, L., Shimizu, K., \& Kochhar, R. (2001). Direct and moderating effects of human capital on strategy and performance in professional service firms: A resource-based perspective. Academy of Management Review, 44(1), 13-28.

Holtbrugge, D., Friedmann, C. B., \& Puck, J. F. (2010). Recruitment and retention in foreign firms in India: A resource-based view. Human Resource Management, 49(3), 439-455.

Hope-Hailey, V. Farndale, E., \& Truss, C. (2005). The HR department's role in organizational performance. Human Resource Management Journal, 15(3), 49-66.

Hughes, J. C., \& Rog, E. (2008). Talent management - A study for improving employee recruitment, retention and engagement within hospitality organizations. International Journal of Contemporary Hospitality Management, 20(7), 743-757.

Huselid, M. A. (1995). The impact of human resource management practices on turnover, productivity, and corporate financial performance. Academy of Management Journal, 38(3), 635-872.

Huselid, M. A., Jackson, S. E., \& Schuler, R. S. (1997). Technical and strategic human resource management effectiveness as determinants of firm performance. Academy of Management Journal, 40(1), 171-188.

Ingram, T. N., Lee, K. S., \& Skinner, S. J. (1989). An empirical assessment of salesperson motivation, commitment, and job outcomes. Journal of Personal Selling and Sales Management, 9, 25-33.

Inyang, B. J. (2011). Creating value through people: Best human resource (HR) practices in Nigeria. International Business and Management, 2(1), 141-150.

Ismail, W. K. W., Omar, R., \& Bidmeshgipour, M. (2010). The relation of strategic human resource practices with firm performance: considering the mediating role of resource based view. Journal of Asia Pacific Studies, 1(3), 395-420.

Jackson, S. E., \& Schuler, R. S. (1995). Understanding human resource management in the context of organizations and their environments. Annual Review of Psychology, 46, 237-264.

Jaffari, S. I. A., Saleem, S., \& Abideen, Z. U. (2011). Few determinants of product and firm performance: A case of FMGC industry. European Journal of Social Sciences, 19(4), 561-572.

Janssens, M., \& Steyaert, C. (2009). HRM and performance: a Plea for reflexivity in HRM studies. Journal of Management Studies, 46(1), 0022-2380.

Jiang, K., Lepak, D. P., Hu, J., \& Baer, J. C. (2012). How does human resource management influence organizational outcomes? A meta-analytic investigation of mediating mechanism. Academy of Management Journal, 55(6), 1264-1294.

Johns, G. (2006). The essential impact of context on organizational behaviour. Academy of Management Review, 31(2), 386-408.

Jusoh, R., Ibrahim, D. N., \& Zainuddin, Y. (2008). The performance consequence of multiple performance measures usage: Evidence from the Malaysian manufacturers. International Journal of Productivity and Performance Management, 57(2), 119-136.

Kaplan, R. S., \& Norton, D. P. (2005). The balanced scorecard - Measures that drive performance. Harvard Business Review, July - August, 1-9.

Katou, A. A. (2012). Investigating reverse causality between human resource policies and organizational performance in small firms. Management Research Review, 35(2), 134-156.

Katou, A. A., \& Budhwar, P. S. (2007). The effect of human resource management policies on organizational performance in Greek manufacturing firms. Thunderbird International Business Review, 49(1), 1-35. 
Katou, A. A., \& Budhwar, P. S. (2009). Causal relationship between HRM policies and organizational performance: evidence from the Greek manufacturing sector. European Management Journal, doi:10.1016/j.emj.2009.06.001

Kaufman, B. E. (2010). A theory of the firm's demand for HRM practices. International Journal of Human Resource Management, 21(5), 615-636..

Kehoe, R. R., \& Wright, P. M. (2010). The impact of high - performance human resource practices on employees' attitudes and behaviours. Journal of Management, , doi: $10.1177 / 0149206310365901$.

Ketkar, S., \& Sett, P. K. (2010). Environmental dynamism, human resource flexibility, and firm performance: Analysis of a multi - level causal model. The International Journal of Human Resource Management, 21(8), 1173-1206.

Khan, W. A. (1990). Psychological conditions of personal engagement and disengagement at work. Academy of Management Journal, 33(4), 692-724.

Kotha, S., \& Swamidass, P. M. (2000). Strategy, advanced manufacturing technology and performance: Empirical evidence from US manufacturing firms. Journal of Operations Management, 18, 257-277.

Lado, A. A., \& Wilson, M. C. (1994). Human resource systems and competitive advantage: A competency-based perspective. Academy of Management Review, 19(4), 699-727.

Lee, J. S., Keil, M., \& Kasi, A. V. (2012). The effect of an initial budget and schedule goal on software project escalation. Journal of Management Information Systems, 29(1), 53-77.

MacDuffie, J. P. (1995). Human resource bundles and manufacturing performance: Organizational logic and flexible production systems in the world auto industry. Industrial and Labour Relations Review, 48(2), 197-221.

Malik, N., \& Aminu, M. (2011). The role of human resource in new globalized world. Interdisciplinary Journal of Contemporary Research in Business, 2(11), 318- 330.

McBain, R. (2004). Uncovering the linkages between HRM and organizational performance. Henley Manager Update, 16(1), 20-28.

McClean, E., \& Collins, C. J. 2011. High commitment HR practices, employee effort, and firm performance: Investigating the efforts of HR practices across employee groups within professional services firms. Human Resource Management, 50(3), 341-363.

Menguc, B. (1996). Evidence for Turkish industrial salespeople, testing the applicability of a conceptual model for the effect of effort on sales performance and job satisfaction. European Journal of Marketing, 30(1), 33-51.

Moideenkutty, U, Al-Lamki, A., \& Murthy, Y. S. R. 2011. HRM practices and organizational performance in Oman. Personnel Review, 40(2), 239-252.

Ngo, H., Lau, C., \& Foley, S. (2008). Strategic human resource management, firm performance, and employee relations climate in China. Human Resource Management, 47(1), 73-90.

Oladipo, J. A., \& Abdulkadir, D. S. (2011). Strategic human resource management and organizational performance in the Nigerian manufacturing sector: An empirical investigation. International Journal of Business and Management, 6(9), 46-56.

Opatha, H. H. D. N. P. (2008). Competences as human assets: a perspective. Sri Lankan Journal of Human Resource Management, 2(1), 62-73.

Paauwe, J. (2009). HRM and performance: achievements, methodological issues, and prospects. Journal of Management Studies, 46(1), 0022-2380.

Paauwe, J., \& Richardson, R. (1997). Introduction. International Journal of Human Resource Management, 8(3), 257-262. 
Panayotopoulou, L., \& Papalexandris, N. (2004). Examining the link between human resource management orientation and firm performance. Personnel Review, 33(5), 499-520.

Park, H. J., Mitsuhashi, H., Fey, C. F., \& Bjorkman, I. (2003). The effect of human resource management practices on Japanese MNC subsidiary performance: A partial mediating model. International Journal of Human Resource Management, 14(8), 1391-1406.

Paul, A. K., \& Anantharaman, R. N. (2003). Impact of people management practices on organizational performances: Analysis of a causal model. International Journal of Human Resource Management, 14(7), 1246-1266.

Pfeffer, J. (2005). Producing sustainable competitive advantage through the effective management of people. Academy of Management Executive, 19(4), 95-106.

Phua, F. T. T. (2006). Predicting construction firm performance: An empirical assessment of the differential impact between industry and firm-specific factors. Construction Management and Economics, 24, 309-320.

Piccolo, R. F., Greenbaum, R., Hartog, D. N. D., \& Folger, R. (2010). The relationship between ethical leadership and core job characteristics. Journal of Organizational Behaviour, 31, 259278.

Priem, R. L., \& Butler, J. E. (2001). Is the resource-based view a useful perspective for strategic management research? Academy of Management Review, 26(1), 22-40.

Purcell, J., \& Hutchinson, S. (2007). Front - line managers as agents in the HRM - performance causal chain: theory, analysis, and evidence. Human Resource Management Journal, 17(1), 320.

Sajeewanie, T. L., \& Opatha, H. H. D. N. P. (2007). Relationships between human resource manager - related factors and practice of strategic human resource management in Sri Lankan listed firms. Sri Lankan Journal of Human Resource Management, 1(1), 71-87.

Schuler, R. S., \& Jackson, S. E. (2005). A quarter-century review of human resource management in the US: The growth in importance of the international perspective. Management Revue, 16(1), 11-35.

Sels, L., Winne, S. D., Delmotte, J., Maes, J., Faems, D., \& Forrier, A. (2006). Linking HRM and small business performance: An examination of the impact of HRM intensity on the productivity and financial performance of small businesses. Small Business Economics, 26(1), 83-101.

Serasinghe, D. K. S., \& Opatha, H. H. D. N. P. (2007). Human resource management practices in listed firms in Sri Lanka. Sri Lankan Journal of Human Resource Management, 1(1), 36-52.

Shaw, J. D., Park, T. Y., \& Kim, E. (2013). A resource-based perspective on human capital losses, HRM investments, and organizational performance. Strategic Management Journal, 34, 572589.

Sheehan, N. T., \& Foss, N. J. (2007). Enhancing the prescriptiveness of the resource - based view through porterian activity analysis. Management Decisions, 45(3), 450-461.

Shih, H. A., Chiang, Y. H., \& Hsu, C. C. (2006). Can high performance work systems really lead to better performance?. International Journal of Manpower, 7(8), 741-763.

Singh, S., Darwish, T. K., Costa, A. C., \& Anderson, N. (2012). Measuring HRM and organizational performance: Concepts, issues, and frameworks. Management Decisions, 50(4), 651-667.

Snell, S. A., \& Dean, J. W. (1992). Integrated manufacturing and human resource management: A human capital perspective. Academy of Management Journal, 35(3), 467-504.

Snell, S. A., \& Youndt, M. A. (1995). Human resource management and firm performance - Testing a contingency model of executive controls. Journal of Management, 21(4), 711-737. 
Southey, G. (2011). The theories of reasoned action and planned behaviour applied to business decisions: A selected annotated bibliography. Journal of New Business Ideas and Trends, 9(1), 43-50.

Subromony, M. (2009). A meta - analytic investigation of the relationship between HRM bundles and firm performance. Human Resource Management, 48(5), 745-768.

Sudin, S. (2004). Human resource practices and organizational performance: Review, synthesis and research implication. International Business Management Conference, Universiti Tenaga Nasional. 99-113

Tangen, S. (2004). Performance measurement: From philosophy to practice. International Journal of Productivity and Performance Management, 53(8), 726-737.

Thang, L. C., \& Quang, T. (2005). Antecedents and consequences of dimensions of human resource management practices in Vietnam. International Journal of Human Resource Management, 16(10), 1830-1846.

Thompson, M., \& Heron, P. (2005). Management capability and high performance work organization. International Journal of Human Resource Management, 16(6), 1029-1048.

Truss, C. (2003). Strategic HRM: Enablers and constraints in the NHS. International Journal of Public Sector Management, 16(1), 48-60.

Tsai, C. J., Edwards, P., \& Sengupta, S. (2010). The associations between organizational performance, employee attitudes and human resource management practices: An empirical study of small businesses. Journal of General Management, 36(1), 1-20.

Tzafrir, S. S. (2006). A universalistic perspective for explaining the relationship between HRM practices and firm performance at different points in time. Journal of Managerial Psychology, 21(2), 109-130.

Waiganjo, E. W., Mukulu, E., \& Kahiri, J. (2012). Relationship between strategic human resource management and firm performance of Kenya's corporate organizations. International Journal of Humanities and Social Science, 2(10), 62-70.

Welter, C., Bosse, D. A., \& Alvarez, S. A. (2013). The interaction between managerial and technological capabilities as a determinant of company performance: An empirical study of biotech firms. International Journal of Management, 30(1), 272-284.

Wright, P. M., Coff, R., \& Moliterno, T. P. (2013). Strategic human capital crossing the great divide. Journal of management, 40(2), 353-370. doi: 10.1177/0149206313518437

Wright, P. M., Dunford, B. B., \& Snell, S. A. (2001). Human resources and the resource based view of the firm. Journal of Management, 27, 701-721.

Wright, P. M., McCormick, B., Sherman, W. S., \& McMahan, G. C. (1999). The role of human resource practices in Petro-chemical refinery performance. International Journal of Human Resource Management, 10(4), 551-571.

Wright, P. M., \& McMahan, G. C. (1992). Theoretical perspectives for strategic human resource management. Journal of Management, 18(2), 295-320.

Wright, P. M., McMahan, G. C., \& McWilliams, A. (1994). Human resources and sustained competitive advantage: A resource-based perspective. International Journal of Human Resource Management, 5(2), 301-326.

Wright, P. M., \& Snell, S. A. (1991). Toward an integrated view of strategic human resource management. Human Resource Management Review. 1(3), 203-225.

Yeo, G. B., \& Neal, A. (2004). A multilevel analysis of effort, practice, and performance: Effects of ability, conscientiousness, and goal orientation. Journal of Applied Psychology, 89(2), 231-247. 
Youndt, M. A., Snell, S. A., Dean, J. W., \& Lepak, D. P. (1996). Human resource management, manufacturing strategy, and firm performance. Academy of Management Journal, 39(4), 836866.

Yousef, D. A. (1998). Satisfaction with job security as a predictor of organizational commitment and job performance in a multicultural environment. International Journal of Manpower, 19(3), 184194.

Zawawi., S. N. H. M., Idris, K. M., \& Rahman, R. A. (2011). Determinants of Behavioural intention of fraudulent financial reporting: Using the theory of reasoned action. Malaysian Accounting Review, 10(1), 43-62.

Zhang, Z., \& Jia, M. (2010). Using social exchange theory to predict the effects of high-performance human resource practices on corporate entrepreneurship: Evidence from China. Human Resource Management, 49(4), 743-765. 